\title{
Conversations About Evolution During Family Visits to an Exhibition About Darwin in a Mexican Museum: An Analysis of Scientific Reasoning
}

\author{
Luisa Massarani ${ }^{1 *}$ (1), Ana Claudia Nepote ${ }^{2}$ (), Jessica Beck ${ }^{3}$ (1), Graziele Scalfi ${ }^{3}$ (1)
}

\begin{abstract}
${ }^{1}$ National Institute of Public Communication of Science and Technology (INCT- CPCT), House of Oswaldo Cruz/Fiocruz, BRAZIL
${ }^{2}$ National School of Higher Studies Morelia Unit, National Autonomous University of Mexico, BRAZIL

${ }^{3}$ National Institute of Public Communication of Science and Technology (INCT- CPCT), BRAZIL

*Corresponding Author: luisa.massarani@fiocruz.br
\end{abstract}

Citation: Massarani, L., Nepote, A. C., Beck, J., \& Scalfi, G. (2022). Conversations About Evolution During Family Visits to an Exhibition About Darwin in a Mexican Museum: An Analysis of Scientific Reasoning. Interdisciplinary Journal of Environmental and Science Education, $18(2)$, e2267. https://doi.org/10.21601/ijese/11520

\section{ARTICLE INFO}

Received: 1 Nov. 2021

Accepted: 15 Dec. 2021

\begin{abstract}
Studies investigating the conversations held in museum settings have proved important for understanding the learning experiences of their visitors. The aim of this mixed-methods study is to analyze the experiences of families on visits to an exhibition on Charles Darwin at Museu Trompo Mágico (Guadalajara, Mexico), particularly their conversations about evolution and what types of scientific reasoning they employed. Ten family groups with a total of 42 visitors participated in the study. The visits were recorded and the audiovisual material loaded into the Dedoose 8.0.23 software, for analysis of the conversations using a protocol which includes three types of reasoning: (i) evolutionary - rudimentary (not in-depth) Darwinian scientific thinking; (ii) intuitive - everyday common-sense explanations; and (iii) mixed - drawing on evolutionary and intuitive reasoning. The results indicate that the exhibition sparked the families' interest and curiosity: in $24 \%$ of the total visit time, they held conversations about evolution-related topics and themes. At that time, the most used reasoning was intuitive reasoning, code applied 124 times, followed by evolutionary reasoning (118 times) and mixed reasoning (120 times). Our results provide evidence that the exhibition brought families closer to scientific knowledge about evolution, prompting conversations about evolutionary terms and topics, in the three types of scientific reasoning investigated. As implications, this study demonstrates that understanding what family members talk about and deciphering how they apply reasoning patterns can help in the definition and structuring of exhibition learning, assist in the reasoning transition process and in the assimilation of concepts that are the basis for understanding evolutionary processes.
\end{abstract}

Keywords: informal education, science museums, scientific reasoning, families

\section{INTRODUCTION}

Conversation is a significant outcome of museum visits, a naturally occurring phenomenon that is shared among visitors (Leinhardt \& Knutson, 2004). Different studies have demonstrated the importance of such experiences in science museums through investigations of dialogue. There are studies that analyze how conversations contribute to learning and the construction of meaning (Allen, 2002; Dierking et al., 2004; Leinhardt \& Knutson, 2004; Zimmerman et al., 2009), how collaborative conversations between parents and children are important for children's understanding of science (Fender \& Crowley, 2007; Haden et al., 2014; Jant et al., 2014), and how family conversations in museums draw on scientific reasoning and evidence (Crowley et al., 2001; Land-Zandstra et al., 2020; Randol, 2005).

Family groups make up a significant proportion of museum visitors (Ellenbogen et al., 2004; McManus, 1994) and share a complex system of experiences through their conversations. It has also been observed that family conversations in museums can enhance engagement and collective learning (Allen, 2004; Bamberger \& Tal, 2008). Therefore, studies that investigate family conversations in museum settings have proved important for better understanding them and contributing to learning experiences. In this study, our aim is to understand the scientific reasoning of families visiting science museums, as this is an important aspect of scientific thinking. According to Bell et al. (2009), in a publication by the National Research Council of the National Academies, understanding scientific reasoning in informal venues allows us to understand how 
families engage in scientific investigation and how they reason and articulate their thinking in conversation with others.

Historically, in the context of science, reasoning "referred to formal reasoning characterized by rules of logic and mathematics" (Sadler, 2004, p. 514). Drawing on the work of Thomas Kuhn (1962, 1991, 1992, 1993), Sadler (2004), Sadler and Zeidler (2005a, 2005b), and Topcu and Sadler (2010) propose two models of reasoning: (i) formal - presenting fixed and immutable premises from which conclusions are drawn, and (ii) informal - presenting assumptions that may change as information becomes available. In the museum context, reasoning is understood as a process that includes cognitive engagement, the skills of asking questions, formulating hypotheses, collecting and using evidence to communicate about thinking, applying causal and contextual thinking, making inferences and revising theories (Bell et al., 2009; Crowley et al., 2001; Kisiel et al., 2012; Land-Zandstra et al., 2020). Besides, can also include previous experiences and knowledge in situations where the individual uses their knowledge to compare or generate a solution for a given task / question, providing evidence of their reasoning (LandZandstra et al., 2020; Zimmerman, 2000).

For Kisiel et al. (2012, p. 1052), studies on reasoning undertaken in informal setting such as science museums emphasize what happens "between and among people rather than 'in the heads' of individuals." Thus, investigating reasoning in museums encompasses visitors' communicative and cognitive activities - activities performed by individuals in an observable way (Kisiel et al., 2012).

Land-Zandstra et al. (2020) analyzed the role of openended questions included in the subtitle for an object - a fossilized dinosaur egg - in the learning process of 66 families visiting the Dutch Natural History Museum (Netherlands). At different times, one by one, the family groups were posed three questions of different levels of complexity - simple ("What does this look like?”), moderate (“This is a REAL dinosaur egg. How big do you think the mother of this dinosaur egg was?”), and complex ("This is a REAL dinosaur egg. What would the breeding place of a dinosaur have looked like?”) - to observe how much the question influenced their reasoning processes. It was found that the moderately complex question facilitated longer conversations with a greater number of complex inferences than the simplest and most complex question. During the longer and more complex conversations, the parents took a more important role in the conversation, mediating the reasoning process of the members of the family group.

Kisiel et al. (2012), who examined family conversations on visits to four aquariums on the west coast of the United States, based their work on mediated action and investigated how scientific reasoning could include cultural tools (displays, elements, and signs) and interaction between individuals. What they found was that families make statements motivated by their observations in the exhibition, question statements made by others, look for information (e.g., reading signs and consulting explainers) to find answers to questions or check something they saw, and look for additional evidence to check, challenge, or confirm a claim (by touching, manipulating, comparing, etc.) in the quest to answer a question. Such practices, which included the use of evidence in argumentation, reinforce the idea that scientific reasoning takes place in such settings.

Based on the above and drawing on a sociocultural perspective of learning (Ellenbogen et al., 2004), we understand that conversations involving reasoning can contribute in important ways to the field of museum learning, as they investigate how understanding and meaning are coconstructed among group members (Hohenstein \& Moussouri, 2018). The conception of learning in this study goes beyond the acquisition of new information to include the expression of emotion, the acquisition of skills, asking questions, and developing evidence-based reasoning (Bell et al., 2009). In particular, in this article we focus on analyzing the reasoning used in family conversations about evolution on a visit to a science museum. In the next section, we present a brief description of studies carried out in this area.

\section{Evolution in Science Museums: Conversations and Reasoning}

Evolution is a fundamental concept for all the life sciences, being addressed systematically in natural history museums (Horn et al., 2016; Sánchez Mora \& Ramírez, 2016) and other science centers and museums (Spiegel et al., 2006). In this sense, these venues play an important role in the public's proximity to, engagement with, and understanding of science (Diamond \& Evans, 2007; Spiegel et al., 2006).

A Gallup (2019) poll found that $40 \%$ of the US adults interviewed had a creationist view of human evolution. However, in a timeline, from the first Gallup poll in 1983 until 2019 , there is a shift in this view with an increasing trend among those who do not believe that human evolution was shaped by divine intervention.

Some studies have shown that most museum visitors have misconceptions about evolution (Guisti, 1994) and have trouble correctly explaining the central mechanisms of evolution, such as natural selection, adaptation, and variation (Borun, 2002; Dunckel et al., 2005). The explanations about evolution given by students - frequent museum visitors (Patiño et al., 2017) - tend to be based on alternative conceptions, sometimes displaying a Lamarckian slant, referring to the use/disuse and inheritance of acquired traits (Bishop \& Anderson, 1990; Brumby, 1984; Sanchez Mora, 2000; Sánchez Mora \& Ramírez, 2016). Another point that is gaining weight around the world has to do with organized antievolution movements, formed by people who resist the idea of evolution (for more details, see Lienesch, 2007).

As such, museums face the challenge of drawing visitors' attention to highly complex concepts (Wilensky \& Reisman, 2006). In order to do so, presenting evolution in a meaningful narrative that addresses knowledge of the history of evolution, including the issue of geological time, adaptation, and fossils, could provide a good context for the acquisition of knowledge about microevolutionary processes (Evans et al., 2015). In addition, using intuitive reasoning - everyday explanations that come to mind when humans solve problems (Evans et al., 2008,2010 ) - as a way of bringing the topic closer to the visitor and using interactive modules that encourage prolonged engagement and social interaction (Horn et al., 2016) have proved promising in providing richer learning experiences for visitors. 
Several studies have been carried out on how people perceive and understand evolution and why this subject remains so controversial (Brumby, 1984; Bishop \& Anderson, 1990; Evans, 2000, 2001; Stein \& Storksdieck, 2005). Some of these studies assess museum visitors' interest in evolution and understanding and acceptance of evolutionary ideas (Dunckel et. al., 2005; Guisti, 1994). Others use exhibitions' exhibits on evolution to understand visitors' understanding of the subject, applying a conceptual model that assesses reasoning (Evans et al., 2010; Tare et al., 2011; Spiegel et al., 2012). For example, Horn et al. (2016) carried out a study at two American natural history museums in which they investigated the involvement and learning of 247 young people aged 8 to 15 in an exhibition module: a touch table that addressed the evolutionary tree of life. They observed that social and physical interaction with the module had a positive impact on learning about evolution.

Evans et al. (2010) interviewed 32 people on visits to the exhibition Explore Evolution hosted at three natural history museums in the Midwestern United States. The study analyzed the visitors' spontaneous perceptions before the visit, investigating several questions about biological change in animals. The answers were analyzed in three reasoning patterns: (i) informed naturalistic reasoning (using Darwinian evolutionary terms in non-specialist language, as well as evolutionary concepts such as variation, inheritance, selection, and time); (ii) novice naturalistic reasoning (using intuitive explanatory concepts, as described above in this item); and (iii) creationist reasoning (making reference to supernatural causes, ranging from explicit statements about divine powers to more implicit references to belief). As a result, $72 \%$ of the participants used scientific and intuitive explanations simultaneously to explain species change. Another $28 \%$ of the participants associated creationist reasoning with scientific and intuitive reasoning in their explanations.

The exhibition Explore Evolution was also investigated by Tare et al. (2011) to analyze the content of conversations between the parents and children of 12 families. The codes used were divided into two main blocks: (i) conversations involving evolutionary and intuitive reasoning and (ii) functional conversations - explanatory (with conversational elements that conveyed or elicited scientific content), nonexplanatory (with conversational elements related to logistics and aspects of the visit), and drawing on text from the exhibition. The authors found that $65 \%$ of the conversations were explanatory and $21 \%$ non-explanatory. The use of evolution-related terms and concepts was identified in $10.2 \%$ of the conversations, while in $12.9 \%$ of the conversations, the parents relied on reading the panels to explain the subject to their children.

In line with the two studies described above, Spiegel et al. (2012) used pre- and post-visit interviews to find out whether there was a conceptual change in children, young people, and adults after a single visit to the museum. The results showed that after visiting the exhibition, the adults and youths increased their use of evolutionary reasoning. In addition, there was an increase in intuitive explanations, which the authors saw as an indication that the visitors' explanations were moving towards evolutionary reasoning.
Together, these studies demonstrate what visitors think and how they understand the theme of evolution in museum spaces. Furthermore, they bring evidence that exhibitions have contributed to the public's understanding of the topic. Despite the value of their contributions, we note that these studies focus on experiences at museums in the United States and Europe (Borun, 2002; Dunckel et. al. 2005; Guisti, 1994; Jiménez \& Muñoz, 2015; Sáez \& Albaladejo, 2017). In Latin America, many interactive science centers and museums were consolidated in the 1990s (Massarani, 2015) and the region still lacks studies focused on understanding the experiences of visitors to these spaces (Massarani et al., 2019a; Rowe \& O'Brien 2016). In particular, Latin American studies on evolution have investigated it in school education (e.g., Bizzo, 1994; Díaz \& Hernández, 2002; León, 2019; León \& Morales, 2017; Tapia \& Arteaga, 2009), with fewer studies turning their attention to the experience of visiting museums and science centers (e.g., González-Medina, 2013; Sánchez Mora \& Ramírez, 2016). Therefore, the understanding of conversations involving reasoning about evolution in the Latin American context is incipient. Building on previous work on conversations involving evolutionary reasoning (Evans et al., 2010; Spiegel et al., 2012; Tare et al., 2011), this study investigates the experience of families visiting an exhibition on Charles Darwin, with particular emphasis on the conversations about evolution and the types of reasoning they used on the subject, in a museum in Mexico. Display quotations of over 40 words, or as needed.

\section{METHOD}

\section{Study Context}

The present study was carried out at the interactive museum Museo Trompo Mágico, in Guadalajara, Mexico. It is part of a larger-scale project on the perspective of visitors on the science museum experience in Latin America (Massarani et al., 2019a, 2019b, 2019c, 2021) and received approval from the ethics committee of the Oswaldo Cruz Foundation (CAAE 10663419.0.0000.5241). Museo Trompo Mágico is run by the Government of the State of Jalisco and is considered a fourthgeneration museum (Gómez, 2004) that focuses on the active learning of visitors to its permanent and temporary exhibitions, which are of a contemplative and interactive nature (Gobierno del Estado de Jalisco, 2015).

Darwin, la exposición - Explorando las especies is a traveling exhibition designed by the American Museum of Natural History (AMNH), New York, about the life and work of Charles Robert Darwin (1809-1882). It covers 7,000-8,000 square feet and has about 500 exhibits, including fossils and live and taxidermized animals (Gobierno del Estado de Jalisco, 2015). It was shown in at least 13 countries until 2015 and attracted approximately four million visitors. In Mexico, it was held at the former Colegio de San Idelfonso, in Mexico City, in 2014, then in 2015 at the Centro Cultural "El Amate" in Cuernavaca. Museo Trompo Mágico was the third Mexican venue for the exhibition, where it remained for three months, from November 1, 2015, to January 31, 2016 (Gobierno del Estado de Jalisco, 2015). 
Table 1. Information on family groups $(G)$ and visit duration

\begin{tabular}{|c|c|c|c|}
\hline Groups & Adults (Relationship) & Children/adolescents (sex / age) & Visit duration \\
\hline $\mathrm{G} 1(\mathrm{n}=4)$ & Mother and father & 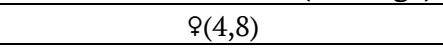 & $19^{\prime} 17 \mathrm{~s}^{\prime \prime}$ \\
\hline $\mathrm{G} 2(\mathrm{n}=3)$ & Father $^{*}$ & $q(2,10)$ & 22’38'” \\
\hline $\mathrm{G} 3(\mathrm{n}=3)$ & Mother & \&(10) and $\sigma^{\top}(13)$ & 60’37’’ \\
\hline $\mathrm{G} 4(\mathrm{n}=3)$ & Aunt and father & $q(8)$ & $36^{\prime} 45^{\prime \prime}$ \\
\hline G5 $(n=5)$ & Mothers & 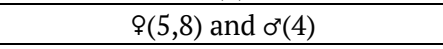 & $12 ’ 47^{\prime \prime}$ \\
\hline G6 $(n=3)$ & Mother & 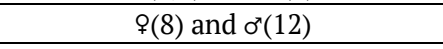 & $60 ’ 53^{\prime \prime}$ \\
\hline $\mathrm{G8}(\mathrm{n}=6)$ & Mothers ${ }^{* * *}$ & $q(5)$ and $\sigma^{r}(3,4,10)$ & $19^{\prime} 56^{\prime \prime}$ \\
\hline G9 $(n=6)$ & Father and grandmother & $q(6,10)$ and $\sigma^{\prime}(6,13)$ & 33'4'” \\
\hline $\mathrm{G} 10(\mathrm{n}=4)$ & Mother & ९(14) and $\sigma^{\prime}(2,8)$ & $20^{\prime} 28^{\prime \prime}$ \\
\hline
\end{tabular}

*Father of 2-year-old and uncle of 10-year-old/***Mother of 4- and 10-year-olds and mother of 5- and 3-year-olds

The exhibition follows a linear, sequential organization and has ten themed rooms on the life and work of Charles Darwin, namely: 1 . the world before Darwin; 2. young naturalist; 3 . a trip around the world; 4 . great discoveries; 5 . the idea takes shape; 6 . a life's work; 7. the study of Darwin; 8. evolution today; 9. endless forms most beautiful; 10 . botanical garden. In these rooms, various topics were discussed, including human evolution, natural selection in animals and plants, micro and macroevolution, and evolutionary time. It portrays Charles Darwin's personal and professional life, his way of life and complex family relationships, his voyage around the world, his discoveries, and the personal challenges he faced until the publication of the theory of evolution by natural selection (Ceci, 2009).

\section{Data Collection}

The data were collected in January 2016. Family groups were approached randomly by the research team at the museum entrance, the only eligibility criteria being those set forth in item 2.3. They were told about the study goals and invited to visit however they wished. Those who demonstrated interest in taking part and gave their authorization for their visit to be recorded picked one child or adolescent from among their number to wear a head-mounted GoPro HERO, which would record the trip by filming subjective, point-of-view footage (Burris, 2017; Lahlou, 2012; Massarani et al., 2019a, 2019b, 2019c, 2021). At the meeting point near the entrance, marking the beginning of the visit, the researcher switched on the group's camera and they set off on their visit. As such, the entire visit was recorded, with audio and video, through this one camera.

\section{Participants}

Ten family groups participated in the study, totaling 42 visitors: 27 females (11 adults, 15 children, and 1 adolescent) and 15 males ( 5 adults, 7 children, and 3 adolescents). The groups were limited to six members to enhance conversation capture, and had to have at least one adult aged 18 or over (mother, father, uncle/aunt, and grandparents) and one child. The age groups of the children were based on the legislation of the Mexican Institute of Youth, published in the Official Gazette of the Federation in 1999, which considers individuals aged up to 11 years old to be children (DOF, 1999). We chose the age groups that included children and adolescents, as they cover a school-age public, when language becomes more conscious and intentional and mental operations are honed, which favors the dialogic process in the family relationship (Elkonin, 1969) (Table 1).

The total visit time, summing the duration of each of the visits by the family groups to the exhibition, was 364 minutes and 46 seconds, with the mean time of each visit being 36 minutes. G7, G6, and G3 were the groups that stayed longest more than one hour - at the exhibition. The shortest visit was by G5 (12 minutes 47 seconds), followed by G1, G8, and G10.

\section{Data Analysis}

The audiovisual material from the visits was inputted into Dedoose 8.0.23, to help with the analysis of the groups' conversations based on the proposed categories. Since some of the material was not directly related to the objective of this article (conversations about evolution), the first stage of the work involved identifying "significant events," namely, segments of conversation in which the participants engaged in conversations on the target topic (Ash et al., 2002). For a segment to be classified as a significant event, it must: (a) have a beginning, middle, and end; (b) have discursive content related to evolution; and (c) include sustained dialogue in which family members demonstrate cognitive engagement and scientific reasoning about evolution.

The studies conducted by Evans et al. (2010), Tare et al. (2011), and Spiegel et al. (2012) served as a reference for classifying the types of reasoning. As identified in the introduction, these authors proposed the study of the types of reasoning used during family conversations about evolution in the exhibition Explore Evolution hosted at different natural history museums in the United States. In this study, the categories and their respective subcategories were adapted in order to cover the evolution-related topics addressed in the exhibition that prompted discussions among the families on their visits. As such, the following categories were included in the analysis: (1) evolutionary reasoning, (2) intuitive reasoning, and (3) mixed reasoning, as defined and exemplified in Table 2, where categories of conversations about evolution and reasoning, number of occurrences, and percentages of categories and sub-categories identified in the family conversations were recorded on the visit to the exhibition Darwin, la exposición - Explorando las especies at Museo Trompo Mágico, Mexico. 
Table 2. Conversations about evolution

\begin{tabular}{|c|c|c|c|c|}
\hline & Definition & Examples & \multicolumn{2}{|c|}{ Occurence } \\
\hline Evolutionary reasoning & \multicolumn{2}{|c|}{$\begin{array}{l}\text { Rudimentary Darwinian thinking: Not like the reasoning of an expert, but spontaneously } \\
\text { evoking terms related to evolution, with the concepts of variation, inheritance, selection, } \\
\text { time, common descent, and ecological pressure }\end{array}$} & 118 & 32.6 \\
\hline Variation & $\begin{array}{l}\text { Refers to the differences between individuals in a } \\
\text { population such as different characteristics and } \\
\text { behaviors, a mutation, or genes }\end{array}$ & Different eye colors in a population & 15 & 12.7 \\
\hline Inheritance & $\begin{array}{l}\text { Refers to the passing of genes from one } \\
\text { generation to the next }\end{array}$ & $\begin{array}{l}\begin{array}{l}\text { Gene for the size of the beak of progenitors and } \\
\text { descendants }\end{array} \\
\end{array}$ & 10 & 8.4 \\
\hline Common descent & $\begin{array}{l}\text { Refers to the common ancestry of organisms, } \\
\text { demonstrating the kinship between different } \\
\text { species or descendants }\end{array}$ & Humanoids and monkeys have the same ancestry & 33 & 28 \\
\hline \multirow[t]{2}{*}{ Selection } & $\begin{array}{l}\text { Natural selection: The idea that organisms with } \\
\text { certain traits that are adapted to an environment } \\
\text { are more likely to survive and pass on these } \\
\text { characteristics to the next generation }\end{array}$ & $\begin{array}{l}\text { Birds with bigger beaks eat bigger and wider seeds } \\
\text { and survive in the environment }\end{array}$ & \multirow[t]{2}{*}{21} & \multirow[t]{2}{*}{17.8} \\
\hline & $\begin{array}{l}\text { Artificial selection: The selection of certain } \\
\text { characteristics of organisms in order to make } \\
\text { future generations more resistant. }\end{array}$ & $\begin{array}{l}\text { Selection of specific traits of plants so they can } \\
\text { resist pests }\end{array}$ & & \\
\hline Time & $\begin{array}{l}\text { Refers to the idea that evolution requires } \\
\text { successive generations before the changes to a } \\
\text { population can be observed /evolutionary time. }\end{array}$ & $\begin{array}{l}\text { Evolutionary change may occur quickly (e.g., } \\
\text { bacteria) or slowly (e.g., whales) }\end{array}$ & 32 & 27 \\
\hline Ecological pressure & $\begin{array}{l}\text { Refers to ecological pressures as causal agents of } \\
\text { diversification or changes in species }\end{array}$ & Corals respond to rising sea temperatures and die & 7 & 6 \\
\hline Intuitive reasoning & \multicolumn{2}{|c|}{$\begin{array}{l}\begin{array}{l}\text { Everyday explanations that come easily to mind when we are solving a problem; common- } \\
\text { sense reasoning }\end{array} \\
\end{array}$} & 124 & 34.3 \\
\hline Intentional & $\begin{array}{l}\text { Anthropomorphization and explanations based } \\
\text { on the mental state (thinking, language), skills, or } \\
\text { conscious effort of the organism to act or change }\end{array}$ & $\begin{array}{l}\text { An organism finds out it likes water and changes } \\
\text { its environment }\end{array}$ & 23 & 18.5 \\
\hline \multirow{2}{*}{$\begin{array}{l}\text { Goal-directed } \\
\text { adaptation }\end{array}$} & $\begin{array}{c}\text { Development: Refers to desire or wish - the } \\
\text { organism develops towards a goal that is yet to be } \\
\text { attained }\end{array}$ & Change based on the animal's desires or wishes & 2 & 0.7 \\
\hline & $\begin{array}{l}\text { Needs: Refers to changes in the organism to meet } \\
\text { a need or purpose; a functional or adaptive } \\
\text { behavior }\end{array}$ & $\begin{array}{c}\text { Changes based on the animal's needs (survival, } \\
\text { bodily and behavioral changes, based on the } \\
\text { environment) }\end{array}$ & 3 & 0.5 \\
\hline
\end{tabular}

Relationship between an organism and its

environment, explaining the existence of a given

organism in a given place or having certain

features, without mentioning environmental

Environment is warm, so a particular animal could be found there change

\section{Analogies and comparisons}

Proximate cause
Association between the evolution topics in the exhibition and previously known facts or everyday life

Refers to a specific agent that brought the organism from one place to another

Refers to the fact that the organism always

existed in a specific place, but was not detected before
Associating the bone morphology of whales' and humans' hands, without making reference to their ancestry

Winds or humans carry plant seeds to different places

No new species emerge, they just exist, but had not been discovered before

\section{RESULTS}

There were 172 conversations about evolution recorded on the family visits, corresponding to $24 \%$ of the total visit time. The breakdown of the different types of reasoning used by the family members is: evolutionary reasoning - 118 occurrences (32.6\%) in 62 conversations; intuitive reasoning - 124 occurrences (34.3\%) in 59 conversations; and mixed reasoning - 120 occurrences $(33.1 \%)$ in 51 conversations. The main categories (evolutionary, intuitive, and mixed reasoning) are mutually exclusive, but the subcategories of the same category may overlap in part of a significant event, which is why the sum of the occurrences exceeds the total number of conversations.
None of the families directly spoke about or expressed ideas based on creationist reasoning - a category investigated in other studies employing a similar analysis (e.g., Evans et al., 2010; Spiegel et al., 2012; Tare et al., 2011) - and they did not avoid evolutionary issues either.

It is worth noting that the family members mentioned evolutionary terms such as "Darwin" and "survival of the fittest" 215 times during the conversations and although some of these terms were only mentioned and were not developed into conversations with scientific reasoning, they stood out for the high number of occurrences. They occurred in response to reading a word on an exhibition panel or after a conversation 
about evolution. Below, we detail and exemplify the three reasoning patterns found.

\section{Conversations Demonstrating Evolutionary Reasoning}

In the evolutionary reasoning category, which covers rudimentary (not in-depth) Darwinian scientific thinking, the most frequently voiced concepts were: common descent $(n=33)$, time $(\mathrm{n}=32)$, natural selection $(\mathrm{n}=21)$, and variation $(\mathrm{n}=15)$. The least frequent concepts were inheritance $(\mathrm{n}=10)$ and ecological pressure $(\mathrm{n}=7)$. Generally, these subcategories co-occurred, as shown in the examples below.

\section{Example 1 - Organisms in different environments (G3)}

$\mathrm{C} 1:$... and then, they went to...? V1: Galapagos islands, where they found the giant turtles we saw [at the beginning of the exhibition] [reading]: "He found plants, birds, and turtles with unique relationships. But they look like the species from the mainland (...)" They're related. Let's see what it says about the Andes [reading] it says that "the mountains rose up little by little.” The gigantic Andes grew with earthquakes like this [showing with hands]. C1: See what it says about the Maldives. "The birds ... contrast with those from the mainland" [reading]. V1: Remember that they were similar here? [on the Galapagos islands] C1: Mm-hm. V1: Here [in the Maldives] they're really different, according to the specimens [common descent/natural selection/time].

\section{Example 2 - Adaptions in cormorants (G6)}

They couldn't fly, but they adapted. They couldn't fly and they lived on an island. What did they do then? C1: They swam. V1: So look at its feet. What were they like? C2: Like a duck's. V1: As if it was a duck, yes. But look more [opens his/her hand]. C2: What's it called? C1: Membranes. C2: Right. V1 [reading]: “They're perfectly adapted to swimming, which is much more useful when it comes to looking for octopuses, their favorite food." C2: Octopuses! V1: "They're wonderfully adapted to their environment. However, when people arrived with dogs, cats, and other animals, the defenseless birds were left at their mercy and now very few exist" [natural selection/variation].

\section{Example 3 - Armored ancestors (G8)}

V1: Look, they think they were like this [glyptodonts and armadillos]. They all end up adapting and evolving. C1: Oh, like in Ice Age? V2: Mm-hm. V1: They believe they were like this at the time of the dinosaurs (...) C4: They think they were like this [points to the biggest] and now they're like this [points to the smallest]. V1: Mm-hm. C4: How do animals evolve with ... C1: Time. They adapt. If there's sunshine, if there's no sunshine ... V2: Exactly. And other factors of natural selection [common descent/time/natural selection/ecological pressure].

The above examples show how the family members engaged cognitively in different ways with evolution-related topics. For example, the adult in G3 encourages the child to think about similarities and differences among island and mainland animals and plants, giving ideas of time, natural selection, and common descent, and recalling information acquired earlier in the exhibition (example 1). In passages like "Let's see what it says about the Andes [reading] it says that 'the mountains rose up little by little,", the subcategory time is evident, with the mother using the information from the exhibition to reinforce the time things take to change, albeit in a superficial manner.

In G6 (example 2), when the daughter expresses curiosity about the membrane of the foot of the island birds, the mother encourages her to think critically and reflect on the changes undergone by the species, drawing on natural selection and variation. Meanwhile, in G8 (example 3), the ideas of time, ecological pressure, and natural selection are used by the children and adult (V2) to talk about evolution, as in the passage:

"C4: How do animals evolve with ... C1: Time. They adapt. If there's sunshine, if there's no sunshine ... V2: Exactly. And other factors of natural selection.”

This group also comment on previous knowledge when the child relates the glyptodon to the movie Ice Age and the adult mentions the time of the dinosaurs.

In one of part of the exhibition, where the families could observe the skeletons of different species, different comments were also observed about the similarities and differences between some of the structures. Some of the family groups saw certain similarities between the species as evidence of common descent, as shown in the following examples.

\section{Example 4 - Similarities between animals (G3)}

V1: Have you noticed that the hand for grasping, the bat's wing for flying, and the fin of the whale for swimming, guess what? C1: What? They're the same? V1: They look alike. Look at image in the panel [reading] "often, they have a very similar structure. For Darwin, their similarity was one more indication that large classes of organisms, such as mammals, share a common ancestor." C1: Wow, they're related [common descent].

\section{Example 5 - Similarities between embryos (G6)}

V1 [reading]: “Darwin was impressed by the similarities between the embryos he removed from the belly of the females." C1: Well, first he, he thought it had to do with the family tree, he thought they had the same distant ancestor or similarities in the big classes. The first embryo is a bat, then a rat and a horse. V1: But they have nothing to do with each other [the animals]. C1: But you can see how similar the embryos are. V1: Mm$\mathrm{hm}$, that's right [common descent].

In G3 (example 4), the mother prompts a comparison between homologous structures of humans, bats, and whales for her children by asking questions, giving explanations, and reading scientific evidence on the exhibition panel. In G6 (example 5), when the youth observes the development of the embryos of different animals, s/he notices that there are few 
differences in the early stages of growth, explaining his/her reasoning to his/her mother upon verifying this fact. In both examples, evidence of similar skeletal structures supports the idea that the animals had a common ancestor at some point in time.

In example 6, the subcategory inheritance - one of the least frequent in the conversations - appears when G6 is intrigued by the similarities in an old photo. Adult V1 begins reading information about the photo and comes across more complex evolutionary concepts, such as genes and mutations. At that point, he redirects his children to another module.

\section{Example 6 - Similarities and genetic inheritance (G6)}

V1: Just look at anyone's face [in the photo] to see the similarity there was. How were these similarities transmitted? [reading] These similarities, genetic inheritance, was never understood during Darwin's lifetime (...) scientists did not really understand the mechanism of inheritance after 1900, when they acknowledged the validity of Mendel's Laws, another scientist. V2: Who's this one? V1: He's an ancestor. You know, honey, they didn't understand because they didn't understand the existence of genes. Do you know what genes are? [C1 and C2 shake their heads] V1: You don't know either? [the children laugh]. V1: Let's go to the next one [module] [inheritance/time].

It is worth mentioning the conversations on the topic of human evolution, which occurred 19 times, in almost all the family groups, with the exception of G2 and G5. Although this subject was not very frequent if compared to the total number of conversations on evolution (172), it is a subject that is normally avoided or not addressed by museum visitors, which is why we regard the fact that the families to this exhibition did talk about it worthy of note. The conversations display cognitive engagement for scientific reasoning in comments that mainly elucidate the processes of change in the subcategory time. Examples of this are illustrated below.

\section{Example 7 - Human evolution (G7)}

V1: Did you see? About humans? C1: Wow! V1: Now we're up there, Homo sapiens, in the present, but we came from there [pointing down], seven million years, the oldest man ever found. He changes one by one until he gets to here [time/common descent].

\section{Example 8 - Human evolution (G10)}

C1: Where are we? V1: Right. Homo sapiens, there! C1: And why are they similar? V2: Here? [pointing at the skulls at the bottom]. Hominids lived seven million years ago. They evolved, they're always changing. Look [showing the hominid family tree]. C1: Are we Homo sapiens? V2: Yes, we started there [pointing at the base of the tree] and we got all the way up there. That's what our skeleton was like, our first head. C1: Oh [time/common descent].

The parents of G7 and G10 (examples 7 and 8) explain to the children about time and common descent in the evolution of hominids.
"V1: Now we're up there, Homo sapiens, in the present, but we came from there [pointing down]" and "V2: Yes, we started there [pointing at the base of the tree] and we got all the way up there. That's what our skeleton was like, our first head.”

The parents also draw on their own previous knowledge in this process, mentioning that humans are Homo sapiens.

\section{Conversations Demonstrating Intuitive Reasoning}

In the category intuitive reasoning, which covers everyday explanations that easily come to mind when solving problems, the strategies most commonly used to explain the evolutionrelated topics were analogies and comparisons $(\mathrm{n}=52)$, intentional $(\mathrm{n}=23)$, and static adaptation $(\mathrm{n}=23)$. The least common strategies were goal-directed adaptation (development, $\mathrm{n}=12$; needs, $\mathrm{n}=13$ ) and proximate cause $(\mathrm{n}=1)$. In this type of reasoning, the co-existence of more than one subcategory in the same conversation was also found, as in examples 9 and 10, where analogies and comparisons and intentional are used by the family members with cognitive engagement strategies

\section{Example 9 - The Monkey Jenny (G3)}

V1 [reading]: “Zoo keepers would often think of the almost human qualities of these animals, dressing them up in children's clothes.” Look, when Jenny, the little orangutan, got angry with her keeper, what do you think she did? C1: What? V1: She fell down onto the ground, kicked and cried. Like who? C1: Like a spoilt child [laughs] V1: Just the same [intentional/analogies and comparisons].

\section{Example 10 - Rhinoceros (G7)}

C1: The same day Darwin made comments about Jenny, he observed that the rhinoceros, which was outside on the first warm day of spring, [reading] "kicked and stood up on its hind legs.” V1: ...with happiness. C1: Yes! [laughs] [intentional/analogies and comparisons].

In the episodes above, the subcategory analogies and comparisons is used by the adults to bring the exhibition content closer to real life and the children's previous experiences, as seen in the excerpt

“Like who? C1: Like a spoilt child” (G3, example 9). Meanwhile, intuitive reasoning used intentionally can be seen in passages like "V1: She [the monkey] fell down onto the ground, kicked and cried" (G3, example 9), and "[the rhino] kicked and stood up on its hind legs" V1:...with happiness.”

In G7 (example 10), where human characteristics, behaviors, and feelings (crying, having a tantrum, having fun, sleeping, enjoying) are used to describe other animals.

One thing worth highlighting from the conversations from the intuitive reasoning category has to do with the questions, explanations, and description of evidence made by children and adolescents themselves about the evolution of animals, using the subcategories intentional and analogies and comparisons, as shown below. 


\section{Example 11 - Armored ancestors (G3)}

V1: Look at that armadillo. Look how big it is! C1: No, the armadillo is that little boy. V1: Which one's bigger. Instead of that big armadillo, right? C1: They're all from the armadillo family. C2: Oh. This is the grandfather, so father and son. C1: I think that's how they are, one that's normal, another that evolves differently, then another, another [evolution] [intentional].

\section{Example 12 - Butterflies (G4)}

C1: Hey look, what pretty butterflies! They look like leaves. Look at that one. It's got owl eyes. V1: Yes, it has. (...) C1 [reading]: "Color is just one way that plants and animals adapt well to places where they live." Really, V1, you have to see this! Here, which of these two is the butterfly? [V1 points]. C1: Both have butterflies. And here, mmm. Another butterfly. One is white as snow and the other is green [analogies and comparisons].

In example 11, the child from G3 associates information $\mathrm{s}$ /he knows about family with the armadillos, using known kinships (father, grandfather, son) to make an association with ancestry. Meanwhile, in example 12, the child from G4 associates the coloring of a butterfly with the color of a leaf and the eyes of an owl:

"C1: Hey look, what pretty butterflies! They look like leaves. Look at that one. It's got owl eyes.”

These analogies and comparisons demonstrate potential for the children to develop understanding of the mechanisms of mimicry and camouflage on other occasions.

Other examples that illustrate how the category intuitive reasoning is used have to do with the way organisms adjust to their environment (static adaptation, $n=23$ ), which is why a given organism is to be found in a given place; and, to a lesser extent, the animals' intrinsic needs for their survival (needdirected adaptation, $\mathrm{n}=13$ ). Sections that fall into these subcategories are shown below.

\section{Example 13 -Armored ancestors (G6)}

C1: That wouldn't be possible if it was still alive. V1: Why not? C1: It wouldn't be able to eat. V1: It wouldn't be able to do what? C1: It wouldn't be able to eat, because there isn't that much special food as there was at that time or not enough for it to survive. V1: Right. [static adaptation].

\section{Example 14 - Color of seeds (G4)}

C1: "Color is just one way plants and animals adapt to the place where they live" [reading]. V1: What do they eat? What color is it? C1: Green. V1: Look, if it's in orange mode [the environment], the green one [seed] will get eaten. If it's in green mode [the environment], the orange one [seed] will get eaten. Do you see? V2: Are they beetles? V1: They're ladybugs. It's about selection. If it's green [environment], the green ones [seeds] survive; they eat orange ones [seeds], if it's orange [environment], the orange ones [seeds] survive [static adaptation /goal-directed adaptation - needs].

\section{Example 15 - Evolution in animals (G8)}

V1: Can you see it? What a big dragonfly. C1: Aha! V1: They were supposed to be big, but they get small, they evolved. C1: What's that? C2: Let me see. Dragonfly. V1: They say that all inhabitants of the earth have an ancestor and evolve according to their needs, you see? Turtles aren't so big any more. C1: It wouldn't survive like that [goal-directed adaptation - needs].

Example 13 shows an attempt by the youth to explain the extinction of the glyptodont, drawing on the concept of static adaptation when s/he mentions that the environmental conditions were not favorable for an animal with such needs to feed. Meanwhile, in example 14, drawing on a reading of the panel, family G4 elaborate questions and explanations on the influence of coloring (in the environment, in animals) on survival in the habitat:

"V1: Look, if it's in orange mode [the environment], the green one [seed] will get eaten. If it's in green mode [the environment], the orange one [seed] will get eaten."

Meanwhile, the same family draws on need-directed adaptation to justify this influence, such as:

"If it's green [environment], the green ones [seeds] survive; they eat orange ones [seeds], if it's orange [environment], the orange ones [seeds] survive."

As for G8 (example 15), the mother also gives the children explanations of how animals evolve, using need-directed adaptation such as

"V1: They were supposed to be big, but they get small, they evolved."

As for goal-directed adaptation - needs - explanations that an animal adapted in response to a conscious desire or intention to change - these were observed primarily (in 7 out of the total of 12 occurrences) in conversations related to the theme of human evolution. The examples presented below provide evidence of how this subcategory was employed.

\section{Example 16 - Human evolution (G6)}

V1: Orangutan skeleton. C1: Look, it's your size. It looks like Nena. [laughs] C2: Hey. V1: Hey, honey, it says that you're like an orangutan, you'll think you haven't evolved. C1: That's right! I'm not a monkey, I want to evolve [goal-directed adaptation - development].

\section{Example 17 - Human evolution (G8)}

V1: Humans came from primates and monkeys. All the others [hominids] were extinct. They all come from that one [hominid] that looks like a monkey. C1: Which one, mom? [V1 points] This one? V1: Look, they think it was like this. C1: Monkey...V1: ...chimpanzees, primates, hominids, and then humans [analogies and comparisons]. 
Both examples contain statements that diverge from currently accepted scientific knowledge. In example 16 (G6), the mother introduces her conception that humans are an evolved form of monkeys and that monkeys did not evolve because they are more primitive. In response to this statement, the adolescent introduces his/her explanation based on development, saying that he isn't an orangutan, and that he wants to evolve. Meanwhile, in example 17, there is a similar statement but it is based on a single evolutionary line reported by the mother of G8:

"V1: Humans came from primates and monkeys."

However, this example shows that the family uses evolutionary thinking and reasoning, because they develop a line of ancestry and indirectly talk about the evolution of individuals over time, as observed in the passage:

"V1: Look, they think it was like this. C1: Monkey...V1: ...chimpanzees, primates, hominids, and then humans."

\section{Conservations Employing Mixed Reasoning}

Conversations that included both evolutionary reasoning and intuitive reasoning were observed in all the groups except for G2 and G5. The families that used mixed reasoning used evolutionary concepts such as selection, time and common descent, demonstrating a more complex pattern of reasoning (evolutionary reasoning), while at the same time giving some goal-directed adaptation related to needs and development, and assuming this was intentional (intuitive reasoning), as shown below.

\section{Example 18 - Armored ancestors (G1)}

V1: ... it's that this is from something that happened a long time ago, from a person who devoted himself to observing animals and seeing how they evolve. Do you think birds were always the way they are now? C1: Yes. V1: Well, no, look, you're quite wrong. Birds used to be different. C1: Don't tell me, like a pterodactyl. V1: Look, see what it says there... "armored," they're like grandparents. That man studied all the grandparents of the animal species that you know today. C1: This one's a... V1: It says here, look. C1 [reading]: “a pygmy armadillo.” So this is this one's grandpa. V1: Right. And it's the same thing with all the animals, honey [time/common descent/intentional/analogies and comparisons].

\section{Example 19 - Plant reproduction (G3)}

V1: Look at plant reproduction. Plants that are pollinated by insects produce more seeds than plants that self-pollinate. Like one plant near another through the air and water, the ones that are aquatic. [reading] "In the struggle of natural selection, plants that exchange pollen should come out better," meaning they should be much better adapted (...) see how the plants are connected, they want to self-pollinate, but if birds help them to pollinate, all the better. C1: Yes [natural selection/ecological pressure/goal-directed adaptation - development /intentional].

\section{Example 20 - Artificial selection in horses (G6)}

V1: Equines, this is a horse [pointing at the leg] and this is now. Look, these are your ancestors. C1: Ah. V1 [explains after reading]: Look, evolution by artificial selection. Humans learned to accelerate the process of evolution. Do you know what they do? C1: What? V1: They cross this horse, which has all these features they like, nice things it has, with this mare, who's also very pretty, and they get married and have better children. C1: Wow [common descent/artificial selection/intentional].

In examples 18,19 , and 20 , the families describe cases of evolution drawing on the concepts of time, common descent, selection, and ecological pressure, and describe the species using human characteristics (e.g., helping, getting married, being pretty, etc.), as in the passages

"but if birds help them to pollinate, all the better." (G3)

and

“and they get married and have better children." (G6)

or human kinship (grandfather, father, and son) (G1):

“V1:(...) they're like grandparents. That man studied all the grandparents of the animal species that you know today."

- an example that also expresses the subcategory intentional. They also draw analogies and comparisons and give needdirected adaptation, as in G6, after V1 reads the passage

"V1: plants that exchange pollen should come out better" and "[plants] want to self-pollinate."

In some conversations, the adults indicate knowledge about the mechanisms of evolution and adaptation, associating them to the theme of the exhibition, as seen in the passages below.

\section{Example 21 - Mimicry in butterflies (G3)}

V1: Look at those owl butterflies. Do you know why they're those colors? C1: Because they look like an owl. Look at the eyes. V1: And also... they land on some trunks, some pine trees, I can't remember the name of the tree, and you can't see them. When they're on the tree, you don't see them. They've camouflaged themselves really well to survive [natural selection/analogies and comparisons/goal-directed adaptation - needs].

\section{Example 22 - Armored ancestors (G6)}

V1 [reading]: Look: “one of Darwin's most remarkable discoveries was the shell of a giant animal like an armadillo. What were these animals? In an excavation, Darwin associated it to the glyptodont.” (...) It could be that the oldest species evolved into new ones over long 
periods of time. Do you all agree? That this armadillo that used to be giant evolved into the forms that we've seen, that we know? C1: YES. V1: What do you think? What about the other one that's totally different? It died and there was another one just the same. C2: It died. C1: It has a common ancestor. V1: Why did it have to be smaller? C1: Yes, because of climate change, there's no food. It's just like Ice Age. V1: Yes. Imagine this [pointing at the oldest one], what it would feed on now there's so little food. Do you think that this big one died and .. just imagine how it could survive today [time/common descent/variation /ecological pressure/analogies and comparisons/goal-directed adaptation - needs].

\section{Example 23 - Armored ancestors (G9)}

C1: Look at the armadillos. Is this one like the ancestor of the super ancestor? [reading]: "Glyptodont, ancestor of the armadillo." C2: Look, what an armadillo! C1: This is the one that lives today, the armadillo. V1: That little boy is our guy today. The big man is the ancestor. C3: It's like a more evolved version of this one. C1: Yes, that's right [NAME], this is the evolution of the evolution. C3: Which one? C1: The little one is the evolution of the evolution. That was the first one, this was one evolution and another. That one from the Ice Age. C3: Yes, I know. V1: And it carries on evolving. V2: Yes, they evolve because at some point in time the glyptodont didn't have enough food, so its diet changed and that's how it evolved. [time/common descent/variation/static adaptation/analogies and comparisons/goal-directed adaptation - development].

In example 21 (G3), when the mother and child talk about mimicry and camouflage, they highlight some features related to the subcategory natural selection, drawing on need-directed adaptation, associating the change intrinsic to the animal to its need for survival, such as:

V1: And also... they land on some trunks, some pine trees, I can't remember the name of the tree, and you can't see them. When they're on the tree, you don't see them. They've camouflaged themselves really well to survive."

In example 22 (G6), these two types of reasoning also appear together in the explanations of the environment and the need for survival. The family make use of evolutionary reasoning to talk about time, common descent, variation, and ecological pressure, and intuitive reasoning for the need-directed adaptation. Both passages contain examples of analogies and comparisons.

What the children and adolescents from G9 say also demonstrates the development of the evolution-related subjects of common descent, time and natural selection, concomitantly with more intuitive explanations (static adaptation and need-directed adaptation) to speak of the animals' evolution, drawing on the texts, as can be seen in example 23, to develop questions and explanations.

\section{DISCUSSION}

The aim of this study was to analyze the experiences of families visiting an exhibition about Charles Darwin, in particular their conversations about evolution and the types of reasoning they used on the subject. The results showed that $24 \%$ of the visit time was occupied by dialogues related to evolution - a significant proportion given the complexity of the topic. The content analysis indicates that, to a greater or lesser degree, the exhibition was able to engage the families in questions about evolutionary processes in the three types of scientific reasoning investigated.

Exhibitions often serve as a starting point for family interactions and conversations. In this study, we found that the exhibition on Darwin presented content that emphasized the time associated with micro- and macroevolution, as well as information on common descent, natural selection of species, and human evolution - topics that influenced what was discussed and the level of knowledge expounded by the families. For example, the content tended to prompt conversations displaying elements of the concepts common descent $(\mathrm{n}=33)$, time $(\mathrm{n}=32)$, natural selection $(\mathrm{n}=21)$, and variation $(\mathrm{n}=15)$, from the category evolutionary reasoning.

In general, the families displayed evidence knowledge related to these subcategories, demonstrating a certain familiarity with evolutionary concepts, as in the common descent subcategory, in which the visitors mentioned the main aspects of ancestry and did not express essentialist thinking. An essentialist perspective sees species as stable and immutable over time, making them unable to change into another species, which makes evolutionary change, particularly the subcategory under discussion, strongly counter-intuitive (Evans, 2000, 2001, 2008; Mayr, 1982).

Despite their high occurrence, the evolutionary concepts present in the subcategories common descent, time, and natural selection were not discussed in depth. Evidence of this occurred when G3 realized that island species were different from mainland species (example 1) and when G6 observed structural adaptations in island birds (example 2). In these examples, the family members mentioned the main concepts that permeate evolution, but made reference to the occurrence of evolutionary mechanisms themselves over time. In summary, the families associated the changes undergone by organisms with their environment, not with the diversity of the members of the species (intraspecific diversity), which acts over generations, as proposed by Darwin in the theory of natural selection or as in genetic mutation, postulated in NeoDarwinism.

Although most visitors were willing to accept evolutionary ideas, the study participants were not sufficiently familiar with the fundamental principles of evolution to understand the mechanisms of evolutionary change proposed by Darwin (Evans et al., 2010). Similarly, other investigations of evolution in formal settings with students from different levels of education, from secondary to undergraduate, found that they apparently accepted the ideas of evolution but often misinterpreted natural selection, relating evolutionary change to pre-Darwinian terms (e.g., Banet \& Ayuso, 2003; Bishop \& 
Anderson, 1990; Brumby, 1984; Evans, 2000, 2001; Nehm \& Reilly, 2007).

Another subcategory that deserves mention in this study is variation. In their discussion of this concept, Evans et al. (2010) state that it is one of the first complex evolutionary concepts to be understood by visitors. They believe that the perception that there are small differences between different members of a given species is an important means of modifying essentialist perspectives (Evans, 2000, 2008). Our data are consistent with this view, demonstrating that the family members noticed some variations within populations. In example 2, for example, the participants comment on different characteristics of birds in the Galapagos Islands. Therefore, our results reinforce the position that understanding there is variation among individuals from a given population (intraspecific diversity) is a crucial step for visitors to understand evolutionary change and the mechanisms of natural selection.

However, in the excerpts of conversation in which variation co-occurred with concepts related to selection, inheritance, and time, it was observed that the families expressed conceptions that diverged from accepted and current knowledge about variation. Our result is in line with the thinking of Bishop and Anderson (1990), who studied the different views of high school students on some evolutionary topics, including variability, and noticed the presence of Lamarckian thinking in the ideas of the use/disuse and inheritance of acquired characters, as in

\section{“They (cheetahs) might have had to run fast to escape predators and gradually their muscles and bones changed to adapt to this".}

Evans et al. (2010) argue that when they can see that an organism's survival in an altered environment depends on particular genetic characteristics, visitors are in a position to understand the main aspects of natural selection: differential survival and differential reproduction (Evans et al. 2010), which, however, was not observed in the examples of this subcategory.

Similarly, between 1998 and 2000, Sánchez Mora and Ramírez (2016) studied the knowledge of Mexican school and university students aged 12 to 20 on evolutionary topics. They reported several problems in the students' interpretations, including: not considering variation or not knowing/understanding its origin; not understanding the role of natural selection; understand evolution as changes in individual organisms and not in populations as a whole; considering evolution only in the past tense. Furthermore, they claimed that evolutionary explanations were based on alternative concepts and reinforced a Lamarckian slant. The same was observed in the family conversations in our study.

Among the less represented categories were inheritance $(\mathrm{n}=10)$ and ecological pressure $(\mathrm{n}=7)$. The inheritance subcategory presents more complex concepts, such as genes and mutations, which may be why it appeared little in the family conversations. This finding is compatible with other studies on evolution with children, adolescents, and adults (Evans et al., 2010; Kargbo et al., 1980; Spiegel et al., 2012). Kargbo et al. (1980) argues that it is common for children to confuse hereditary and non-hereditary characteristics in populations and that some individuals, even of an older age, believe that environmentally induced characteristics, such as the lack of a finger, can be transmitted to offspring under certain circumstances. Our results suggest that these difficulties in understanding genetic inheritance extend into adulthood, as seen in example 6 (G6), which shows that the adult directs children to another module, apparently because they do not know how to explain what genes are.

In their investigation of the knowledge of 14- and 15-yearold students of evolution, Jiménez-Aleixandre et al. (2000) found that the topic inheritance was difficult to understand, as it requires a certain capacity for abstraction. Banet and Ayuso (2003) suggest that this topic can be introduced through more general subjects, referring to easily recognizable characteristics of humans or pet animals. In the exhibition studied here, a family photograph was used in the topic Inheritance, but it was chosen to address the history of the discovery of genes. In our view, the exhibition could have addressed the topic by associating genes with characteristics similar to the ones of the family members in the photograph. Therefore, although it was not our objective to analyze the exhibition, we believe that this choice may have influenced the visitors' understanding.

The subcategory ecological pressure also appeared very little ( $n=7)$, with example 3 (G8) being one of the exceptions, in the passage where $\mathrm{C} 1$ points out environmental conditions as one of the evolutionary factors of the species

\section{"C4: Time. They adapt. If there's sunshine, if there's no sunshine".}

Evans et al. (2010) mention that an important insight in this subcategory is the perception of visitors that environmental changes exert significant pressure on organisms, as in the example on finches: "They adapted fairly quickly to the change in food," without relating it to natural selection. Our data contrast with those of Evans et al. (2010) and Spiegel et al. (2012), who identified this subcategory in several statements by the visitors they interviewed. In this study, the low association of species changes with ecological pressure may be related to the fact that the family groups only made associations with the organism-environment relationship as a causal agent of this diversification, without considering environmental action itself.

We highlight the conversations about human evolution that took place in the evolutionary reasoning category. In these dialogues, cognitive engagement for scientific reasoning was observed in comments about the change processes, as in example 7 (G7), where V1 mentions the evolutionary lineage of hominids, and example 8 (G10), where V1 uses prior knowledge to show the child where humans are in the evolutionary lineage and the skeletal changes that have occurred over time. In contrast, other studies that have covered reasoning patterns (e.g., Evans, 2000, 2008; Evans et al., 2010) have noted that visitors avoid the topic of human evolution, based on religious and cultural issues and on the controversial nature of common descent.

In the conversations employing intuitive reasoning, the most frequent subcategory was analogies and comparisons 
$(\mathrm{n}=52)$, drawing associations between the evolutionary contents seen in the exhibition and real-life events and family experiences. Discussing the ways of learning about science involving parents and children, Bell et al. (2009) argue that associating scientific thinking with pleasant and engaging events related to everyday life can create important connections on a personal and collective level, while also serving as a strategy for attracting the public to an exhibition (Silva \& Gomes, 2009; Soares et al., 2013). Furthermore, these strategies make the subject more understandable for children and adolescents (Leinhardt et al., 2002). In this sense, sharing previous and personal experiences (Zimmerman et al., 2009) helps to give meaning to an exhibition experience (Massarani et al., 2019a), as seen in example 1 (G3), when family members refer to knowledge acquired earlier in the exhibition, or in examples 3 (G8), 22 (G6), and 23 (G9), which make reference to the movie Ice Age.

Occurring in equal measure in the families' conversations in our study were the subcategories intentional and static adaptation, appearing 23 times each. In the former case, the participant used human characteristics, behaviors, and feelings to describe the organisms. This behavior may be associated with a type of unconscious language based on the assumption that attributing anthropomorphic characteristics to animals will make it easier to understand what is being shown in the exhibition (Tare et al., 2011). Rigney and Callanan (2011) state that adults often employ this kind of discourse in reference to typical animals, with specific features and movements, and which somehow encourage children to anthropomorphize. Such patterns were identified in this study, in excerpts when the G3 adult mentioned human behavioral characteristics in monkeys (example 9), when the G7 adult mentioned human feelings in rhinos (example 10), and the G3 child associated human kinships to armadillos (example 11).

As for the subcategory static adaptation - the reason why an organism can be found in a certain place - Evans et al. (2010) state that visitors used alternative conceptions such as referencing the organism-environment relationship to justify the organism's existence in that environment. For SánchezMora (2000), visitors are unable to understand that environmental conditions only affect the persistence and dispersion of existing characteristics in organisms. In line with the work of these authors, our data provide evidence that family members associated alternative concepts to the organism-environment relationship as one of the only reasons for an organism to be found in a particular environment or to have certain characteristics, without mentioning other factors as possible agents of change or diversification, as seen in examples 13 (G4) and 14 (G6).

The least used subcategories in the intuitive reasoning category were goal-directed adaptation - needs $(\mathrm{n}=13)$ and development $(\mathrm{n}=12)$ and proximate cause $(\mathrm{n}=1)$. When the needdirected explanations subcategory was mentioned by family members, it was linked to the influence of the environment on survival, as in the excerpt

"V1: If it's green [environment], the green ones [seeds] survive; they eat orange ones [seeds]" (example 14, G4)

or
“V1: You see? Turtles aren't so big any more. C1: It wouldn't survive like that" (example 15, G8).

This occurred because family members directed their thoughts to the animal's intrinsic needs, characterized as the changes necessary for survival (Evans et al., 2010). In these examples, it is evident that visitors believe that necessity results in evolutionary change, employing a Lamarckian view, introducing evidence of a pattern of mixed reasoning, discussed below. This pattern was also observed in need-directed adaptation, for example in the excerpt

\section{"so its diet changed and that's how it evolved" (example 23, G9).}

During the mixed reasoning conversations, a possible bridge was noticed between common sense and scientific knowledge, which shows once again that belief in evolutionary ideas is no guarantee of understanding evolutionary mechanisms, but may be essential in the transition between thoughts. In addition to the aforementioned co-occurrences, this reasoning frequently occurred between the subcategories analogies and comparisons and common descent $(\mathrm{n}=12)$ and time $(\mathrm{n}=11)$. Episodes that highlight these associations were illustrated in example 18 (G1), where different degrees of kinship (grandfather, father, and son) were called on to talk about the ancestry of animals, and in examples 22 (G6) and 23 (G9), in which family members made associations with prior knowledge about dinosaurs and animals from the movie Ice Age. These examples demonstrate the anthropomorphization of characteristics and behaviors to characterize the organisms, possibly as a simpler way to introduce the evolutionary mechanism of natural selection into children's scientific thinking, as well as being a way for visitors to appropriate the ideas presented, using them more easily in their own explanations and assimilations.

Chief among the less frequent occurrences of this reasoning is need-directed adaptation together with the subcategories ecological pressure $(n=1)$, variation $(n=1)$, and inheritance $(\mathrm{n}=0)$ and development-directed adaptation with the same subcategories of ecological pressure $(n=1)$, variation $(n=1)$, and inheritance $(\mathrm{n}=1)$. These results reinforce the Lamarckian view used by the visitors to explain evolutionary change, associating the use and disuse of structures and inheritance of acquired features instead of environmental pressure, intraspecific variation, and genetic change as an evolutionary justification. As stated by Bishop and Anderson (1990), we believe that when visitors use explanations based on need and development, they ignore pre-existing variability within species and describe change in individual terms, with organisms developing out of their own will or need. In such cases, visitors should be introduced to examples and explanations based on the Darwinian perspective.

To sum up, the integration of intuitive, religious, or scientific beliefs is a long process and the gaps between these conceptions seem to be filled by a variety of transitional concepts, reflecting various combinations of intuitive and evolutionary ideas (Spiegel et al., 2012). In this sense, our data provide evidence that family members use such reasoning in their conversations and that they may simultaneously rally alternative and scientific concepts in mixed reasoning as a way 
to build their own evolutionary knowledge, using intuitive reasoning as a basis to reflect on and argue about evolutionary problems.

\section{CONCLUDING REMARKS}

Our study provides evidence that Darwin, la Exposición Explorando las Especies sparked the interest and curiosity of family groups, introducing them to scientific knowledge about evolution, eliciting conversations about evolution-related topics in which they used different reasoning patterns.

In general terms, the families engaged in a cognitive effort to establish conversations with a meaningful narrative about evolution for the group, mainly encompassing the scientific concepts of geological time and common descent, from the evolutionary reasoning category. The high occurrence of these concepts could be interpreted as an indication of the importance of the knowledge and inclusion of human beings in evolutionary history in a timeline. In other words, understanding where we "fit into" the story of evolution seems to be an important aspect for the families in the conversations in this category. Also in this reasoning, we highlight the skills used by the families, such as critical thinking and reflection, when talking about and discussing the most varied scientific concepts during the visit. Another important point in the evolutionary reasoning conversations is that the families were not sufficiently familiar with the Darwinian mechanisms of evolutionary change (Evans et al., 2010), often using alternative and Lamarckian conceptions. Furthermore, such conversations did not employ microevolutionary processes involving more complex concepts, such as genes and mutations, which may indicate difficulty in interpreting the content on display.

In the intuitive reasoning conversations, the families explained and interpreted the evidence on the themes exposed, making use of causal connections and their previous knowledge, using analogies and comparisons as the main strategy. In short, these conversations revolved around explanatory reasoning, supported by everyday thoughts, involving causality and contextualization. Although these conversations have been approached superficially, with incomplete concepts and mechanisms and alternative conceptions, we recognize that they play an important role in conceptual development and learning experiences, especially in the children, who asked different questions, made different predictions, and analyzed evidence, which we recognize as having potential for them to express their reasoning in the museum environment.

The presence of mixed reasoning - intuitive and evolutionary - in the same significant event reinforces the idea that both forms of reasoning coexist in the thoughts and arguments of the families, in which evolutionary explanations were observed emerging from previous intuitive ideas and vice versa. In this way, we reinforce the importance of common sense reasoning, since its application could mark out an initial path in the conceptual transition between forms of reasoning.

As limitations of this study, we emphasize that the results cannot be generalized, as this was a qualitative study carried out at an exhibition on Charles Darwin at the Mexican museum
Trompo Mágico; indeed, this was not our intention due to the scope of the study. However, although other research is obviously needed to analyze how knowledge about visitors develop scientific thinking and reasoning in Latin American science museums, our findings are important for studies in the field of science education as they provide evidence that families engage in conversations involving reasoning to understand the complex topics inherent to the subject, which are instrumental in their learning experiences.

We also sustain that understanding what family members talk about and what reasoning patterns they use may help the education teams at science museums to design exhibitions that help develop a contextualized narrative, employing strategies that encourage visitors to connect different types of reasoning and to understand the differences between them.

For such, museums need to ensure that what they design and exhibit establishes effective communication with the public (Sánchez Mora \& Ramírez, 2016), since the exploration and conversations that take place in these spaces can be attributed to the exhibition design in particular. (Crowley et al., 2001). In this process, it would be interesting for the exhibition to address the evolutionary theme in a playful way, based on geological and geographic concepts, as it is a simpler way to understand evolution (Katakos \& Athanasiou, 2020). Also, use leaner and more exemplary texts, focusing on less technical terms and more on understanding the concepts of your visitors. Many of the conversations about evolutionary, intuitive, and mixed reasoning came from previous readings of the exhibition texts, suggesting that this is an important source of information that should be improved in museums and science centers. The use of prior knowledge, linked to films and drawings, would also be a way of introducing this complex topic to the experience of visitors during the exhibition.

This would enable exhibitions to convey fundamental concepts more successfully and enable visitors to engage in deeper conversations about evolutionary processes and mechanisms, resulting in greater understanding and acceptance of the central ideas of evolution by the general public.

Author contributions: All co-authors have involved in all stages of this study while preparing the final version. They all agree with the results and conclusions.

Funding: No external funding is received for this article.

Declaration of interest: The authors declare that they have no competing interests.

Ethics approval and consent to participate: Not applicable.

Availability of data and materials: All data generated or analyzed during this study are available for sharing when appropriate request is directed to corresponding author.

\section{REFERENCES}

Allen, S. (2002). Looking for learning in visitor talk: A methodological exploration. In G. Leinhardt, K. Crowley, \& K. Knutson (Eds.), Learning conversations in museums (pp. 259-303). Erlbaum. 
Allen, S. (2004). Designs for learning: Studying science museum exhibits that do more than entertain. Science Education, 88(Suppl. 1), S17-S33. https://doi.org/10.1002/ sce. 20016

Ash, D., Crain, R., Brandt, C., Loomis, M., Wheaton, M., \& Bennett, C. (2007). Talk, tools and tensions: Observing biological talk over time. International Journal of Science Education, 29(12), 1581-1602. https://doi.org/10.1080/ 09500690701494118

Bamberger Y., \& Tal T. (2008). Multiple outcomes of class visits to natural history museums: The students' view. Journal of Science Education and Technology, 17, 274-284. https://doi.org/10.1007/s10956-008-9097-3

Banet, E., \& Ayuso, G. E. (2003). Teaching of biological inheritance and evolution of living beings in secondary school. International Journal of Science Education, 25(3), 373-407. https://doi.org/10.1080/09500690210145716

Bell, P., Lewenstein, B., Shouse, A. W., \& Feder, M. A. (2009). Learning science in informal environments: People, places, and pursuits. A Report of the National Research Council of the National Academies. The National Academies Press.

Bishop, B. A., \& Anderson, C. W. (1990). Student conceptions of natural selection and its role in evolution. Journal of Research in Science Teaching, 27(5), 415-427. https://doi.org/10.1002/tea.3660270503

Bizzo, N. M. V. (1994). From down house landlord to Brazilian high school students: What has happened to evolutionary knowledge on the way? Journal of Research in Science Teaching, 31(5), 537-556. https://doi.org/10.1002/ tea.3660310508

Borun, M. (2002). Being human: A design in process, four focus groups. University of Pennsylvania Museum: Museum Solutions.

Brumby, M. N. (1984). Misconceptions about the concept of natural selection by medical biology students. Science Education, 68(4), 493-503. https://doi.org/10.1002/ sce.3730680412

Ceci, C. (2009). Darwin: Origin and evolution of an exhibition. Evolution, Education and Outreach, 2, 560-563. https://doi.org/10.1007/s12052-008-0110-3

Crowley, K., Callanan, M., Jipson, J., Galco, J., Topping, K., \& Shrager, J. (2001). Shared scientific thinking in everyday parent - child activity. Science Education, 85, 712-732. https://doi.org/10.1002/sce.1035

Diamond J., \& Evans E. M. (2007). Museums teach evolution. Evolution, 61(6), 1500-1506. https://doi.org/10.1111/ j.1558-5646.2007.00121.x

Diario Oficial de la Federación (DOF). (1999). Ley del Instituto Mexicano de la Juventud [Law of the Mexican Institute of Youth]. http://www.dof.gob.mx/nota_detalle.php?codigo= 4943094\&fecha=06/01/1999

Díaz, F., \& Hernández, G. (2002). Estrategias docentes para un aprendizaje significativo: Una interpretación constructivista [Teaching strategies for meaningful learning: A constructivist interpretation]. Editorial Mc Graw Hill.
Dierking, L. D., Ellenbogen, K. M., \& Falk, J. H. (2004). In principle, in practice: Perspectives on a decade of museum learning research (1994-2004). Science Education, 88(Suppl. 1), S1-S96. https://doi.org/10.1002/sce.20021

Dunckel, B. A., Ellis, S., MacFadden, B. J., Dierking, L. D., Abraham-Silver, L., Kisiel, J., \& Koke, J. (2005). Natural history museum visitors' understanding of evolution by natural selection: Florida Museum of Natural History Evolution Project Report. Florida Museum of Natural History, University of Florida.

Elkonin, D. B. (1969). Característica general del desarrollo psíquico de los niños. [General characteristic of children's psychic development]. In A. A. Smirnov, A. N. Leontiev, S. L. Rubinsthein, \& B. M., Tieplov (Eds.), Psicología (pp. 493503). Grijalbo.

Ellenbogen, K. M., Luke, J. J., \& Dierking, L. D. (2004). Family learning research in museums: An emerging disciplinary matrix? Science Education, 88(Suppl. 1), S48-S58. https://doi.org/10.1002/sce.20015

Evans, E. M. (2000). The emergence of beliefs about the origins of species in school-age children. Merrill-Palmer QuarterlyJournal of Developmental Psychology, 46, 221-254.

Evans, E. M. (2001). Cognitive and contextual factors in the emergence of diverse belief systems: Creation versus evolution. Cognitive Psychology, 42, 217-266. https://doi.org/10.1006/cogp.2001.0749

Evans, E. M. (2008). Conceptual change and evolutionary biology: a developmental analysis. In S. Vosniadou (Ed.), International handbook of research on conceptual change. (pp. 263-294). Routledge.

Evans, E. M., Spiegel, A. N, Gram, W., Frazier, B. F., Tare, M., Thompson, S., \& Diamond, J. (2010). A conceptual guide to natural history museum visitors' understanding of evolution. Journal of Research in Science Teaching, 47(3), 326-353. https://doi.org/10.1002/tea.20337

Evans, E. M., Weiss, M., Lane, J., \& Palmquist, S. (2015). The spiral model: Integrating research and exhibit development to foster conceptual change. In D. M. Sobel, \& J. Jipson (Eds.), Cognitive development in museum settings: Relating research and practice (pp. 36-64). Psychology Press.

Fender, J. G., \& Crowley K. (2007). How parent explanation changes what children learn from everyday scientific thinking. Journal of Applied Developmental Psycology, 28(3), 189-210. https://doi.org/10.1016/j.appdev.2007.02.007

Gallup. (2009). National science education standards. National Academy Press. https://news.gallup.com/poll/21814/ evolution-creationism-intelligent-design.asp

Gobierno del Estado de Jalisco - México. (2015). Llegada Darwin al museo Trompo Mágico [Darwin arrival at the Trompo Mágico museum]. https://www.jalisco.gob.mx/es/ prensa/noticias/30317.

Gómez, O. G. (2004). La apuesta educativa del “Trompo Mágico" museo interactivo de Guadalajara. [The educational commitment of the Guadalajara "Trompo Mágico” interactive museum]. Mediaciones, 2(3), 167-179. https://doi.org/10.26620/uniminuto.mediaciones.2.3.2004 .167-179 
González-Medina, J. P. (2013). Viaje de un naturalista en el Museo de la Ciencia y el juego. Experiencias de divulgación de la biología a través de la lúdica. [The journey of a naturalist at the Museum of Science and Game. Experiences of divulgation of biology through ludic activities]. Biográfia, Escritos Sobre la Biología y sus Enseñanzas [Biography, Writings on Biology and its Teachings], 6(1), 195-204. https://doi.org/10.17227/ 20271034.11biografia195.204

Gregory, T. R. (2009). Understanding natural selection: Essential concepts and common misconceptions. Evolution Education Outreach, 2,156-175. https://doi.org/10.1007/ s12052-009-0128-1

Guisti, E. (1994). Summative evaluation of the hall of human biology and evolution. What can we learn from visitors. American Museum of Natural History.

Haden, C. A., Jant, E. A., Hoffman, P. C., Marcus, M., Geddes, J. R., \& Gaskins, S. (2014). Supporting family conversations and children's STEM learning in a children's museum. Science Direct, 29(3), 333-344. https://doi.org/10.1016/ j.ecresq.2014.04.004

Hohenstein, J., \& Missouri, T. (2018). Museum learning: Theory and research as tools for enhancing practice. Routledge. https://doi.org/10.4324/9781315696447

Horn, M. S., Phillips, B. C., Evans, E. M., Block, F., Diamond, J., \& Shen, C. (2016). Visualizing biological data in museums: Visitor learning with an interactive tree of life exhibit. Journal of Research in Science Teaching, 9999(00), 1-24. https://doi.org/10.1002/tea.21318

Jant, E. A., Haden, C. A., Uttal, D. H., \& Babcock, E. (2014). Conversation and object manipulation influence children's learning in a museum. Child Development, 85(5), 20292045. https://doi.org/10.1111/cdev.12252

Jiménez, A. G. \& Muñoz, A. M. (2015). Análisis de las hipótesis evolutivas en alumnos de educación secundaria y bachillerato [Analysis of the evolutionary hypotheses of secondary education and high school students]. Revista Electrónica de Enseñanza de las Ciencias [Electronic Journal of Science Teaching], 14(1), 35-54.

Jiménez-Aleixandre, M. P., Bugallo Rodríguez, A., \& Duschl, R. A. (2000). Doing the lesson? Or doing science?: Argument in high school genetics. Science Education, 84(6), 757-792. https://doi.org/10.1002/1098-237X(200011)84:6<757:: AID-SCE5>3.0.CO;2-F

Kargbo, D. B., Hobbs, E. D., \& Erickson, G. L. (1980). Children's beliefs about inherited characteristics. Journal of Biological Education, 14(2), 137-146. https://doi.org/10.1080/ 00219266.1980 .10668980

Kisiel, J., Rowe, S., Vartabedian, M. A., \& Kopczak, C. (2012). Evidence for family engagement in scientific reasoning at interactive animal exhibits. Science Education, 96(6), 10471070. https://doi.org/10.1002/sce.21036

Kuhn, D. (1991). The skills of argument. Cambridge University Press. https://doi.org/10.1017/CBO9780511571350

Kuhn, D. (1992). Thinking as argument. Harvard Educational Review, 62, 155-178. https://doi.org/10.17763/haer.62.2. 9r424r0113t67011
Kuhn, D. (1993). Science as argument: Implications for teaching and learning scientific thinking. Science Education, 77(3), 319-337. https://doi.org/10.1002/sce.373 0770306

Kuhn, T. S. (1962). The structure of scientific revolutions. University of Chicago Press.

Land-Zandstra, A. M., Hoefakker, K., \& Damsma, W. (2020). Reasoning about objects in a Natural History Museum: The effect of complexity of questions on object labels. Visitor Studies, 23(2), 218-236. https://doi.org/10.1080/ 10645578.2020.1781485

Leinhardt, G., \& Knutson, K. (2004). Listening in on museum conversations. AltaMira Press.

Leinhardt, G., Crowley, K., \& Knutson, K. (Eds.). (2002). Learning conversations in museums. Erlbaum. https://doi.org/10.4324/9781410606624

León, E. (2019). Estrategias de enseñanza utilizadas en clases de evolución biológica. [Teaching strategies used in biological evolution classes]. Telos, 21(1), 144-165. https://doi.org/10.36390/telos211.08

León, E., \& Morales, M. (2017). Experiencia didáctica: Las tic en la enseñanza de la evolución biológica. [Didactic experience: Tics in teaching of biological evolution]. Revista Eduweb, 11(1), 101-112. https://doi.org/10.15332/ s1657-107X.2018.0001.03

Lienesch, M. (2007). In the beginning: Fundamentalism, the scopes trial, and the making of the antievolution movement. University of North Carolina Press.

Massarani, L. (2015). Voices from other lands. Public Understanding of Science, 24(1), 2-5. https://doi.org/10.1177/0963662514563888

Massarani, L., Fazio, M. E., Rocha, J. N., Dávila, A., Espinosa, S., \& Bognanni, F. A. (2019b). La interactividad en los museos de ciencias, pivote entre expectativas y hechos empíricos: el caso del Centro Interactivo de Ciencia y Tecnología Abremate (Argentina) [Interactivity in science museums, pivot between expectations and empirical facts: the case of the Abremate Interactive Science and Technology Center (Argentina)]. Ciência \& Educação (Bauru), 25(2), 467-484. https://doi.org/10.1590/1516731320190020012

Massarani, L., Mucci Poenaru, L., Norberto Rocha J., Rowe, S., \& Falla, S. (2019c). Adolescents learning with exhibits and explainers: the case of Maloka. International Journal of Science Education, Part B, 9(3), 253-267 https://doi.org/10.1080/21548455.2019.1646439

Massarani, L., Norberto Rocha, J., Scalfi G., Silveira Y., Cruz, W., \& Lage dos Santos Guedes L (2021). Families visit the museum: A study on family interactions and conversations at the Museum of the Universe - Rio de Janeiro (Brazil). Frontiers in Education, 6, 669467. https://doi.org/10.3389/feduc.2021.669467 
Massarani, L., Reznik, G., Norberto, J., Falla, S., Rowe, S., Martins, A. D., \& Amorim, L. (2019a). A experiência de adolescentes ao visitar um museu de ciência: Um estudo no museu da vida [Adolescents' experience when visiting a science museum: A study in the museum of life]. Ensaio: Pesquisa em Educação em Ciências, 21, e10524. https://doi.org/10.1590/1983-21172019210115

Mayr, E. (1982). The growth of biological thought. Belknap.

McManus, P. M. (1994). Families in museums. In R., Miles, \& L. Zavala (Eds.), Towards the museum of the future: New European perspectives (pp. 81-97). Routledge.

National Research Council. (2009). Learning science in informal environments: People, places, and pursuits. National Academies Press.

Nehm, R. H., \& Reilly, L. (2007). Biology majors' knowledge and misconceptions of natural selection. BioScience, 57(3), 263-272. https://doi.org/10.1641/B570311

Patiño Barba, M. L., Padilla González, J., \& Massarani, L. (2017). Diagnóstico de la divulgación de la ciencia en América Latina: Una mirada a la práctica en el campo. [Diagnosis of science dissemination in Latin America: A look at the practice in the field]. RedPOP, Unesco.

Randol, S. M. (2005). The nature of inquiry in science centers: Describing and assessing inquiry at exhibits [Unpublished doctoral dissertation]. University of California.

Rigney, J. C., \& Callanan, M. A. (2011). Patterns in parentchild conversations about animals at a marine science center. Cognitive Development, 26(2), 155-171. https://doi.org/10.1016/j.cogdev.2010.12.002

Rowe S., \& O’Brien, S. (2016). Pesquisa sobre aprendizagem em museus: Um campo em busca de foco? [Research on learning in museums: A field in search of focus?]. In L. Massarani, R. Neves, \& L. Amorim (Orgs). Divulgação científica e museus de ciências: O olhar do visitante Memórias do evento. Museu da Vida/Casa de Oswaldo Cruz/Fiocruz; RedPop, 104p.

Sadler, T. D. (2004). Informal reasoning regarding socioscientific issues: A critical review of research. Journal of Research in Science Teaching, 41(5), 513-536. https://doi.org/10.1002/tea.20009

Sadler, T. D., \& Zeidler, D. L. (2005a). The significance of content knowledge for informal reasoning regarding socioscientific issues: Applying genetics knowledge to genetic engineering issues. Science Education, 89(1), 71-93. https://doi.org/10.1002/sce.20023

Sadler, T. D., \& Zeidler, D. L. (2005b). Patterns of informal reasoning in the context of socioscientific decision making. Journal of Research in Science Teaching, 42(1), 112-138. https://doi.org/10.1002/tea.20042

Sáez, S. P. C., \& Albaladejo, C. M. (2017). La evolución biológica en las exposiciones del Museo Nacional de Ciencias Naturales [Biological evolution in the exhibitions of the Museo Nacional de Ciencias Naturales]. Evolución, 12(1), 73-79.
Sánchez Mora, M. C. (2000). La enseñanza de la teoría de la evolución a partir de las concepciones alternativas de los estudiantes [Teaching the evolution theory from students' alternative conceptions]. [Doctoral dissertation, Facultad de Ciencias, División de estudios de posgrado México]. Repositorio Universitario Especializado en Comunicación Pública de la Ciencia.D.F: UNAM. http://ru.ameyalli. dgdc.unam.mx/handle/123456789/12?show=full

Sánchez Mora, M. C., \& Ramírez, C. L. (2016). Efectos sobre el aprendizaje informal de la evolución biológica como resultado de la mediación museal [Effects on informal learning of biological evolution as a result of museum mediation]. Revista Eureka sobre Enseñanza y Divulgación de las Ciencias [Eureka Magazine on Science Teaching and Dissemination], 13(2), 315-341. https://doi.org/10.25267/ Rev_Eureka_ensen_divulg_cienc.2016.v13.i2.07

Silva, T. C. R., \& Gomes, A. C. F. (2009). A importância dos desenhos animados como representação ideológica: Formação da identidade infantil [The importance of cartoons as an ideological representation: Formation of children's identity]. Iniciação Científica CESUMAR [Scientific Initiation CESUMAR], 11(1), 37-43.

Soares, B. C., Vieira, B. M., \& Fonseca, L. C. S. (2013). Procurando Nemo: O uso da animação para o ensino de ciências [Finding Nemo: Using animation for science teaching]. Revista da SBEnBio, 7, 936-948.

Spiegel, A. N., Evans, E. M., Frazier, B., Hazel, A., Tare, M., Gram, W., \& Diamond, J. (2012). Changing museum visitors' conceptions of evolution. Evolution Education Outreach, 5, 43-61. https://doi.org/10.1007/s12052-0120399-9

Spiegel, A. N., Evans, E. M., Gram, W., \& Diamond, J. (2006). Museum visitors' understanding of evolution. Museums \& Social Issues, 1(1), 69-86. https://doi.org/10.1179/ msi.2006.1.1.69

Stein, J. K., \& Storksdieck, M. (2005). Life changes museum visitor survey: Summary of results. Institute for Learning Innovation.

Tapia, F., \& Arteaga, Y. (2009). Estrategias para la enseñanza de la célula aplicadas por docentes de educación básica [Strategies for teaching the cell applied by basic education teachers]. Revista Educare [Education Magazine], 13(1), 97120. https://doi.org/10.46498/reduipb.v13i1.265

Tare, M., French, J., Frazier, B. N., Diamond, J., \& Evans, E. M. (2011). Explanatory parent-child conversation predominates at an evolution exhibit. Wiley Periodicals, Inc. https://doi.org/10.1002/sce.20433

Topcu, M. S., Sadler, T. D., \& Yilmaz-Tuzun, O. (2010). Preservice science teachers' informal reasoning about socioscientific issues: The influence of issue context. International Journal of Science Education, 32(18), 24752495. https://doi.org/10.1080/09500690903524779

Wilensky, U., \& Reisman, K. (2006). Thinking like a wolf, a sheep, or a firefly: Learning biology through constructing and testing computational theories-An embodied modeling approach. Cognition and Instruction, 24(2), 171209. https://doi.org/10.1207/s1532690xci2402_1 
Zimmerman, C. (2000). The development of scientific reasoning skills. Developmental Review, 20(1), 99-149. https://doi.org/10.1006/drev.1999.0497
Zimmerman, H. T., Reeve, S., \& Bell, P. (2009). Family sensemaking practices in science center conversations. Science Education, 94, 478-505. https://doi.org/10.1002/sce.20374 